Article

\title{
Strategic Development of Product-Service Systems (PSS) through Archetype Assessment
}

\author{
Trine Brink Frederiksen *, Marina P. P. Pieroni (D, Daniela C. A. Pigosso (D) and Tim C. McAloone \\ Department of Mechanical Engineering, Technical University of Denmark (DTU), DK-2800 Kgs, Lyngby, \\ Denmark; mdpp@mek.dtu.dk (M.P.P.P.); danpi@mek.dtu.dk (D.C.A.P.); tmca@dtu.dk (T.C.M.) \\ * Correspondence: trinebf@hotmail.com
}

Citation: Frederiksen, T.B.; P. P.

Pieroni, M.; Pigosso, D.C.A.;

McAloone, T.C. Strategic

Development of Product-Service Systems (PSS) through Archetype Assessment. Sustainability 2021, 13, 2592. https://doi.org/10.3390/ su13052592

Academic Editor: Jihwan Lee

Received: 14 January 2021

Accepted: 22 February 2021

Published: 1 March 2021

Publisher's Note: MDPI stays neutral with regard to jurisdictional claims in published maps and institutional affiliations.

Copyright: (c) 2021 by the authors. Licensee MDPI, Basel, Switzerland. This article is an open access article distributed under the terms and conditions of the Creative Commons Attribution (CC BY) license (https:/ / creativecommons.org/licenses/by/ $4.0 /)$.

\begin{abstract}
Product-service systems (PSS) enable product-oriented manufacturing companies to differentiate their offerings and become more competitive, while creating more value for customers along with improved economic performance and, in some cases, reduced environmental impact. However, PSS development remains difficult for manufacturing companies due to limited prior knowledge about PSS and the strategic characteristics it entails. To guide the PSS development process, this paper presents a prescriptive approach composed of a tool and a method based on the use of PSS archetypes in the initial development stages of new PSS business models (BM). The proposed tool builds upon three PSS archetypes, combined with 10 factors for assessment of the best suiting archetype. The proposed method and supporting tool guide companies in five steps, from the beginning of a servitisation process to the initial PSS development. Based on an evaluation with a Danish manufacturing company, an improved version of the method and tool was developed and applied with 60 students specialised in PSS development. Results from the evaluation indicate that the method and tool support scoping new PSS BM through the selection and modification of a PSS archetype, encouraging servitisation and PSS development in companies with different levels of PSS experience.
\end{abstract}

Keywords: product-service systems; business model; archetypes; method; tool

\section{Introduction}

Product-Service Systems (PSS) have been gaining attention from academics and practice throughout the past decades [1]. A PSS is a strategy for business model innovation that seeks to integrate products and services with the potential to decouple business success and economic growth from pure product sales [2].

The PSS research field emerged in the 1990's from the fields of business management and sustainability research [3]. While in the beginning, PSS research was related primarily to an environmental focus [4,5], it gained an economic focus after 2010 [6], coincidently with the dissemination of the overlapping servitisation theory $[7,8]$.

PSS implementation can trigger multiple business benefits, which ultimately vary according to the different types of PSS (i.e., product-, use-, or result-oriented) $[4,9,10]$. The main benefits can be clustered into four groups: (i) Increased market competitiveness [6,9]; (ii) additional customer value [6,9,11]; (iii) improved economic performance [6,12,13]; and (iv) reduced environmental impact $[9,12,14,15]$. The fourth cluster of benefits has received special attention lately, since PSS has increasingly been explored as part of a company's transition from a linear to a circular economy (CE) aiming at an enhanced sustainability performance [9,16-21]. PSS-based business models are frequently highlighted as fundamental to unleashing a CE transition [22] due to their potential to enable economic gains and growth decoupled from resource consumption [10,18,23].

As described by Tukker [4], the three different types of PSS (i.e., product-oriented, use-oriented, and results-oriented) enable different levels of potential improvement with 
regards to environmental sustainability. The product-oriented PSS presents the lowest level of potential improvement, while the result-oriented offers the highest level of potential approvement [4]. However, PSS business models are not intrinsically environmentally sustainable [24]. The actual environmental impact of the developed PSS business model is not only affected by the type of PSS, but also by potential rebound effects associated to them. Hence, selecting the right type of PSS for a given business model is a fundamental first step to enable a company to seize environmental benefits on top of economic benefits. The selection of the most beneficial PSS type should be followed by an integration of eco-design best practices in the further development of the business model, including more thorough assessments of rebound effects [23-26].

To achieve the potential benefits linked with PSS, manufacturing companies usually undergo a servitisation process [27]. Servitisation refers to the transformational process of an organisation (i.e., the reconfiguration of operational capabilities) from being mainly product-oriented towards providing service-oriented business models or PSS-oriented business models. PSS is the strategy for the business model development process aimed at fulfilling a specific market need [28].

From a management research point of view, the transition captured by the concept of servitisation remains poorly understood, and limited research has been conducted on complete methodologies for the process of servitisation [29]. One example is the Snakes and Ladders model for servitisation by Andrews et al. [30], which divides servitisation into four phases:

- $\quad$ The exploration phase: Initial learning about PSS and the opportunities that it provides for the organisation, which result in an initial proposal for a PSS business model;

- the evaluation phase: Evaluation and communication of the business potential of servitisation through pilot projects with a few selected customers;

- the expansion phase: The PSS is scaled from individual customer projects to development and implementation of a complete PSS solution offered throughout the organisation, including changes in organisational structure;

- the final exploitation phase: Continuous optimisation and delivery of the PSS offering.

While PSS development is an important part of the servitisation process, PSS development can also exist without servitisation, for example, in new service-oriented companies or in cases where PSS is developed in parallel to a company's normal activities without any other changes in organisational capabilities and structures [27,31]. PSS development is often initiated by companies when drivers (or low barriers) in combination with factors indicating a potential benefit of PSS for the specific company (i.e., within the four groups of aforementioned benefits) are observed $[5,12,13]$. However, a well-planned development process is essential to achieve the potential benefits of a PSS. In particular, it is important to ensure that the PSS offering will actually provide added value for the customers [9,32].

Despite the potential synergies of strategically managing the servitisation and PSS development processes concurrently, Baines et al. [29] observed that research addressing the combination of the servitisation and PSS development fields is scant. In practice, while several manufacturing companies have already started their implementation of PSS business models, this is usually done in an ad-hoc way and as a response to a direct customer demand rather than a desire to expand PSS development systematically to the core of their value creation and business model innovation processes [12].

Opportunities for further research lies in the combination of the process of organisational change implied by the servitisation and the servitisation outcome represented by the PSS development along with service delivery [33]. This combination could help to identify factors for influencing the successful adoption of services, new business models, and paths for PSS development [29].

PSS development is initiated at a strategic business level focused on defining the overall strategy for the PSS business model [11,34], whereas the process of servitisation begins already at the first exploration of PSS and the benefits related to it [30]. The process of servitisation begins even before the PSS development is initiated, and a successful 
transition could therefore be influenced already in the stage of exploration of PSS and the benefits related to it, by linking the processes of servitisation and PSS development.

One of the challenges faced by companies in the exploration stage is to identify how to translate the expected benefits that they want to capture with servitisation into the exact PSS business model, while mitigating potential risks [35]. To implement PSS successfully, companies require knowledge about the concept of PSS and a systematised approach with interrelated tools and frameworks for PSS development [36,37]. Extensive research exists in the field of PSS development, with several approaches available, as also covered by the multiple reviews of methodologies for PSS development [37-39]. Examples of such frameworks, methods, and tools for PSS development are the transition framework by Pieroni et al. guiding the development of PSS business models with a focus on the new value proposition [40], the method by Barquet et al. focused on generating PSS proposals in the fuzzy front-end of PSS development [41], the integrative frameworks suggested by both Adrodegari et al. and PROTEUS comprising all stages of PSS development including specific tools for each step [2,42], and the framework by Adrodegari et al. supporting the description and analysis of 9 specific components for PSS BM development [43]. Despite the diversity of these frameworks, methods, and tools, approaches that specifically support the selection of the best suiting PSS archetype depending on the companies' characteristics and expected benefits are scant [44].

To address that, this research develops a method (i.e., step-by-step approach) and an accompanying tool to support companies with: (i) The exploration of different PSS types and their benefits (e.g., economic and environmental) or risks that come with the choices; and (ii) the definition of the overall strategy of the PSS business model that will trigger the PSS development. The concept of archetypes is used as a backbone for the tool that aims to guide companies in assessing how to translate benefits and balance risks for proposing promising PSS business models. Archetypes are comparable to 'theoretical prototypes' [45] describing recurrent groupings of elements used to design business models according to a specific purpose, such as service or PSS design [45-48].

The paper is structured in six sections. Section 2 describes the methodology applied in the research. Section 3 presents the developed tool and the method for its application, including the identification of 10 factors for PSS archetype selection. Section 4 explains the evaluation and improvement rounds of the tool and method with a manufacturing company and design engineering students. Finally, discussion and conclusion (Section 5) outline the contributions, limitations, and directions for future research.

\section{Research Methodology}

To ensure a structured research approach building on existing literature, the Design Research Methodology (DRM) proposed by Blessing and Chakrabarti [49] was employed. The research was organised in six phases:

\subsection{Phase 1: Research Clarification}

This phase served to define the research gap, which emerged from the need for an approach for linking the initial servitisation and the strategic PSS development stages (Figure 1). It comprised a systematic literature review following the methodology specified by Biolchini et al. [50]. Data collection was performed in the Scopus database, based on search strings combining the keywords servitisation, PSS development, and approach/process together with relevant synonyms.

The systematic literature review confirmed that PSS development is typically initiated at a strategic business level focused on defining the overall strategy for the PSS business model $[11,34]$ (i.e., how the business model looks like), whereas the process of servitisation begins with a first exploration of PSS and the benefits related to it [30] (i.e., why to pursue PSS business models). Hence, a structured approach able to link the company's first exploration of PSS (i.e., the "why" or purpose for doing it) with the actual deployment of the strategy into a PSS business model is lacking. The concepts of archetypes and typologies 
from the literature review were also identified as useful for integrating extensive knowledge about PSS characteristics (i.e., how to configure the business models) and effects (i.e., why do it, or results obtained) $[4,51]$. Hence, PSS archetypes were selected as the backbone to guide the development of an approach for guiding companies in the initial stages of servitisation and PSS development. While previous research on PSS archetypes is mostly descriptive, this study takes a prescriptive approach, as also suggested by Chiu et al. [44]. PSS archetypes are used as a means to transfer knowledge and experience from existing PSS business models, generating recommendations for the development of new business models according to different organizational drivers for servitisation (e.g., circular economy strategies, market positioning).

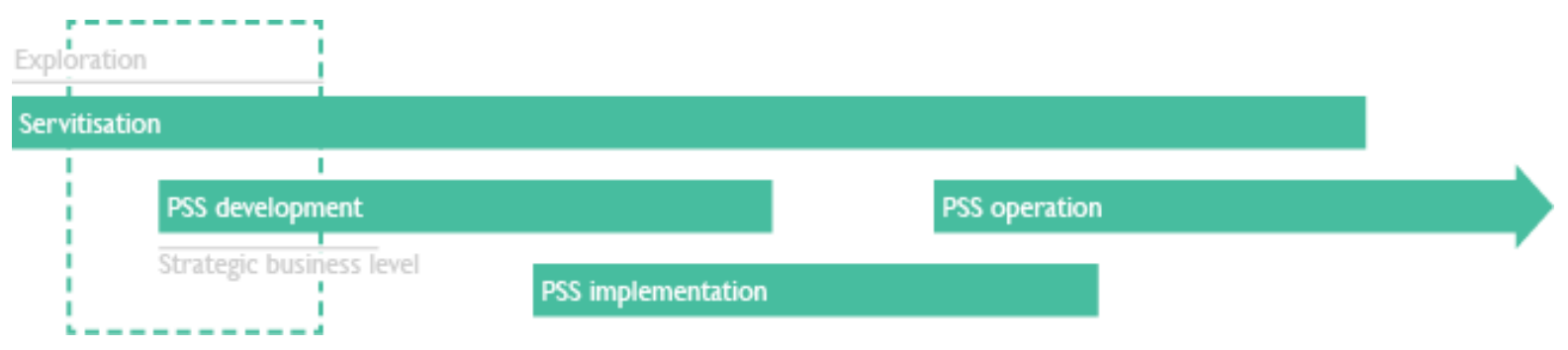

Figure 1. Research gap combining the initial stages of servitisation and Product-Service Systems (PSS) development.

\subsection{Phase 2: Descriptive Study 1}

This phase served to define a clear set of archetypes to be used as a foundation for the method and accompanying tool. The identification of archetypes was based on existing PSS literature retrieved from the Scopus database. Subsequently, a case-based analysis using nine paradigm cases of existing PSS [52] was applied to elaborate and clearly distinguish the characteristics of the three identified archetypes.

\subsection{Phase 3: Prescriptive Study 1}

The aim of this phase was to apply the knowledge gained from the previous phases for the proposal of a method (i.e., step-by-step approach) and accompanying tool to guide manufacturing companies in planning PSS development.

Based on an iterative process, the tool was conceptualised based on an analysis of which factors usually affect the choice of different PSS archetypes. A list of 10 factors for PSS archetype selection was formulated based on the results of the Descriptive Study 1 and supplemented by further literature about the choice of PSS archetypes. The 10 factors are the core logic for the tool for PSS archetype assessment.

The method (i.e., step-by-step approach) for applying the tool was conceptualised based on the expected inputs and outputs generated by the tool along with a specified support outline [49]. The approach was developed with a practitioner-oriented perspective, targeting the manufacturing companies that seek to explore the transition towards service-oriented business models. This was ensured through collaboration with a case company from the equipment and machinery manufacturing sector, which was available for interviews, research visits, and frequent consultation. The elaborated approach was deployed into a prototype, which went through a primary internal evaluation before the formal evaluation conducted with the manufacturing company as part of the Descriptive Study 2. The resulting step-by-step approach, the accompanying tool, and the 10 factors for PSS archetype selection are described in details in Section 3.

\subsection{Phase 4: Descriptive Study 2}

In this phase, the applicability and the usefulness of the method in the context of the manufacturing company was evaluated, and improvement opportunities were identified. The method was tested in three workshops with a Danish manufacturer of non-domestic cooling and ventilation equipment (i.e., NACE code 28.25) [53]. 
The case company was a business unit of a global manufacturing company supplying equipment for HVAC applications and industrial cooling, amongst others. As the company was experiencing a growing demand for more performance- and outcome-based contracts, they wanted to explore PSS development as an opportunity to extend value creation through service provision. As their current business model was based on a traditional product-oriented approach with a service offering limited to support upon customer requests, the existing knowledge about PSS development and servitisation was limited. However, the awareness about the benefits of PSS business models was broadly acknowledged. In particular, stronger customer relationships and improved profit margins were recognised as some of the primary drivers for PSS representing a good business opportunity. In addition, from the strategic management level, a push for more service-oriented business models was evident, by their corporate strategy specifying a goal of at least 5\% of the contribution to come from services by 2022. Altogether, a clear motivation towards PSS development was observed in the organisation, although until the current stage it had been hindered by the strong product focus, the uncertainty of change and the lack of knowledge about PSS business models and their development.

\subsection{Phase 5: Prescriptive Study 2}

Based on the insights gained from the evaluation in the Descriptive Study 2, improvement opportunities for the method and specifically for the tool for PSS archetype assessment were explored. Hence, second versions of the tool and the overall method were developed through iterations of ideation and evaluation of their coherence and structure.

\subsection{Phase 6: Descriptive Study 3}

In this phase, the new versions of the method and accompanying tool were evaluated with regards to applicability and usefulness in the context of an Engineering Master's course with 60 students applying the archetype assessment tool and the method for further development of an existing PSS business model.

The method and tool were evaluated with the Design Engineering students through a workshop focused primarily on the tool for PSS archetype assessment, but also involving the other steps of the method. The participants were divided into 13 groups. After the workshop, the assessments and the business models specified through the morphology were shared with the researchers for evaluation of the results. Furthermore, the workshop was concluded by an oral evaluation of the method and accompanying tool, complemented by a questionnaire focused on the 10 factors for PSS archetype selection and the participants understanding of those, representing the core logic of the tool. Based on the results and feedback from the Design Engineering students, limitations for the application of the tool were identified, indicating topics for further research.

\section{Results}

This section is structured in two parts. First, the tool for PSS archetype assessment is introduced (Section 3.1), together with its foundations-i.e., the three PSS archetypes (i.e., results of the Descriptive Study 1) and the 10 factors for PSS archetype selection (i.e., results of Prescriptive Study 1). In the second part, the method for strategic development of PSS and application of the tool for PSS archetype selection is described (Section 3.2).

\subsection{Tool for PSS Archetype Assessment}

The goal of this tool is to identify the best suiting PSS archetype for the specific manufacturing company based on their current readiness and vision.

\subsubsection{PSS Archetypes Available in the Tool}

The PSS archetypes incorporated in the tool were derived from the PSS typology developed by Tukker [4]. The PSS archetypes are clustered under three groups: (i) Productoriented services, (ii) use-oriented services, and (iii) result-oriented services. To expand 
their definitions and clearly distinguish the type of any given PSS business model, other typologies $[34,44,51,54]$ were used to add complementary characteristics that could contribute to the identification of each PSS archetype. The final characteristics of the three applied PSS archetypes (i-iii) are summarized in Table 1.

Table 1. The three PSS archetypes and their characteristics (derived from $[4,34,44,51,54]$ ).

\begin{tabular}{|c|c|c|c|c|}
\hline Characteristics & Product-Oriented & Use-Oriented & Result-Oriented & Reference \\
\hline $\begin{array}{l}\text { Product/service } \\
\text { ownership }\end{array}$ & Customer & Provider & Provider & {$[4,44,54]$} \\
\hline \multirow{3}{*}{ Service type } & $\begin{array}{l}\text { Maintenance and } \\
\text { consultancy }\end{array}$ & Rental or leasing services & $\begin{array}{l}\text { Integrated solutions } \\
\text { (personalised features) }\end{array}$ & {$[44]$} \\
\hline & $\begin{array}{l}\text { Product-related advice } \\
\text { and consultancy }\end{array}$ & $\begin{array}{l}\text { Product lease, renting, } \\
\text { and pooling }\end{array}$ & $\begin{array}{l}\text { Activity management } \\
\text { Pay-per-service-unit } \\
\text { Functional result }\end{array}$ & [4] \\
\hline & $\begin{array}{l}\text { Services providing added } \\
\text { value to product lifecycle }\end{array}$ & $\begin{array}{l}\text { Services providing } \\
\text { enabling platform to } \\
\text { customer }\end{array}$ & $\begin{array}{l}\text { Services providing final } \\
\text { result to customer }\end{array}$ & {$[34,51]$} \\
\hline Payment & Per product & Per use & $\begin{array}{l}\text { Per result (contract } \\
\text { based) }\end{array}$ & {$[4,44,54]$} \\
\hline $\begin{array}{l}\text { Provider responsible } \\
\text { for cost of activities in } \\
\text { the use phase }\end{array}$ & No & Yes & Yes & {$[4,34]$} \\
\hline
\end{tabular}

\subsubsection{Criteria for Assessment and Selection of PSS Archetypes}

When applying the support tool, the best suiting PSS archetype is identified through a self-assessment questionnaire based on 10 factors for PSS archetype selection. The 10 factors were derived from literature as part of the primary conceptualisation of the tool. They describe certain characteristics of a company's business model that lead to the development of certain types of PSS. Table 2 outlines the 10 factors identified as decisive for the choice of PSS archetype along with a description for each factor.

Table 2. The 10 factors for PSS archetype selection derived from $[4,27,44,54-60]$.

\begin{tabular}{|c|c|c|c|c|c|}
\hline Factor & Ref. & Description & Product-Oriented & Use-Oriented & Result-Oriented \\
\hline $\begin{array}{l}\text { Ability to } \\
\text { predict customer } \\
\text { behaviour }\end{array}$ & {$[4]$} & $\begin{array}{l}\text { The tree types of PSS entail different } \\
\text { requirements for the company's } \\
\text { ability to predict customer } \\
\text { behaviour, e.g., a result-oriented } \\
\text { PSS requires the highest level of } \\
\text { predictability in order to be able to } \\
\text { deliver a guaranteed result. }\end{array}$ & $\begin{array}{c}\text { No/To a very low } \\
\text { extent }\end{array}$ & $\begin{array}{l}\text { To a limited } \\
\text { extent }\end{array}$ & $\begin{array}{l}\text { Yes/To a high } \\
\text { extent }\end{array}$ \\
\hline $\begin{array}{l}\text { Freedom to } \\
\text { fulfil customer } \\
\text { needs }\end{array}$ & [4] & $\begin{array}{l}\text { A result-oriented PSS with a high } \\
\text { degree of freedom to fulfil the } \\
\text { customer needs (due to the product } \\
\text { only serving as a tool) will be more } \\
\text { beneficial for providers that are able } \\
\text { to offer alternative ways to fulfil the } \\
\text { need. }\end{array}$ & $\begin{array}{l}\text { Not useful (Only } \\
\text { offer one solution) }\end{array}$ & & High potential \\
\hline $\begin{array}{c}\text { Type of } \\
\text { customer } \\
\text { relationship }\end{array}$ & [55] & $\begin{array}{l}\text { The changes in customer } \\
\text { relationship involved in a change } \\
\text { from product-oriented towards use- } \\
\text { and result-oriented PSS entails } \\
\text { longer and more formalised } \\
\text { customer relationships. }\end{array}$ & Short term & & Long term \\
\hline
\end{tabular}


Table 2. Cont.

\begin{tabular}{|c|c|c|c|c|c|}
\hline Factor & Ref. & Description & Product-Oriented & Use-Oriented & Result-Oriented \\
\hline $\begin{array}{l}\text { Investment vs. } \\
\text { operational cost } \\
\text { incurred by } \\
\text { customers }\end{array}$ & {$[54,56]$} & $\begin{array}{l}\text { If a product implies a relatively } \\
\text { high investment, some potential } \\
\text { customers might be limited } \\
\text { from buying it, thus } \\
\text { representing a good } \\
\text { opportunity for result-oriented } \\
\text { PSS, which will enable } \\
\text { customers to make use of the } \\
\text { product without the investment } \\
\text { cost. }\end{array}$ & $\begin{array}{l}\text { Low investment }+ \\
\text { Low operation and } \\
\text { Low investment }+ \\
\text { high operation }\end{array}$ & $\begin{array}{c}\text { High operation + } \\
\text { High investment } \\
\text { andLow } \\
\text { investment + } \\
\text { High operation }\end{array}$ & $\begin{array}{c}\text { High investment }+ \\
\text { Low } / \text { High } \\
\text { operation and } \\
\text { High operation }+ \\
\text { Low investment }\end{array}$ \\
\hline $\begin{array}{l}\text { Stage of } \\
\text { industry } \\
\text { lifecycle }\end{array}$ & {$[27,55,57]$} & $\begin{array}{l}\text { Business models are shaped by } \\
\text { the business situation including } \\
\text { external forces, market forces, } \\
\text { industry forces, and } \\
\text { macro-economic forces. } \\
\text { Additionally, according to [10], } \\
\text { PSS development is "a response } \\
\text { to the challenges and } \\
\text { opportunities they [the } \\
\text { company] face in their industry } \\
\text { lifecycle" }\end{array}$ & Early stages & & Late stages \\
\hline $\begin{array}{l}\text { Competition } \\
\text { intensity }\end{array}$ & [58] & $\begin{array}{l}\text { "Results suggest that } \\
\text { competition in the } \\
\text { manufacturing industry } \\
\text { prompts firms to provide } \\
\text { product-oriented services" [35], } \\
\text { thus indicating a link between } \\
\text { the level of competition and the } \\
\text { type of PSS. }\end{array}$ & $\begin{array}{l}\text { Competition by } \\
\text { price }\end{array}$ & & $\begin{array}{l}\text { Competition by } \\
\text { differentiation }\end{array}$ \\
\hline $\begin{array}{c}\text { Modularity/ } \\
\text { customisation }\end{array}$ & [54] & $\begin{array}{l}\text { The level of customisation of } \\
\text { the product affects its eligibility } \\
\text { for different PSS types, since } \\
\text { customised goods lead to a } \\
\text { preference to user's ownership. } \\
\text { Moreover, the more customised } \\
\text { the product is in terms of } \\
\text { adaptation, the less potential } \\
\text { the PSS will have for reusability } \\
\text { and scalability, whereas } \\
\text { standardised products generate } \\
\text { more useful data for } \\
\text { result-based fees and feedback } \\
\text { to product development. }\end{array}$ & $\begin{array}{l}\text { The product is } \\
\text { individually } \\
\text { customised for the } \\
\text { customer or built } \\
\text { from special fitted } \\
\text { parts }\end{array}$ & $\begin{array}{l}\text { The product is } \\
\text { based on a } \\
\text { combination of } \\
\text { standard and } \\
\text { customised parts }\end{array}$ & $\begin{array}{l}\text { The product is } \\
\text { standardised or } \\
\text { configured purely } \\
\text { from standard } \\
\text { parts }\end{array}$ \\
\hline $\begin{array}{l}\text { Company's } \\
\text { ownership }\end{array}$ & {$[4,44,59]$} & $\begin{array}{l}\text { The change of ownership of the } \\
\text { product caused by use- and } \\
\text { result-oriented PSS archetypes } \\
\text { will require a considerable } \\
\text { change in the organisation and } \\
\text { its business model, thus } \\
\text { affecting the choice of PSS } \\
\text { archetype. }\end{array}$ & No & Parts of it & Yes \\
\hline
\end{tabular}


Table 2. Cont.

\begin{tabular}{|c|c|c|c|c|c|}
\hline Factor & Ref. & Description & Product-Oriented & Use-Oriented & Result-Oriented \\
\hline $\begin{array}{c}\text { Organisational/ } \\
\text { Business } \\
\text { Investment }\end{array}$ & {$[4,55]$} & $\begin{array}{l}\text { A crucial factor for companies } \\
\text { deciding on a type of PSS is the } \\
\text { required change in } \\
\text { organisational culture, which } \\
\text { differs across the types of PSS. } \\
\text { The company also needs to } \\
\text { assess its goodwill and ability of } \\
\text { investment for the PSS } \\
\text { development. }\end{array}$ & No & & Yes \\
\hline $\begin{array}{l}\text { Ambitions for } \\
\text { environmental } \\
\text { sustainability }\end{array}$ & {$[4,60]$} & $\begin{array}{l}\text { Environmental sustainability is } \\
\text { one of the main benefits of PSS } \\
\text { business models, depending on } \\
\text { the type of PSS. Therefore, } \\
\text { ambitions for environmental } \\
\text { sustainability were included as } \\
\text { a motivation affecting the } \\
\text { choice of PSS archetype. }\end{array}$ & As little as possible & & $\begin{array}{l}\text { As much as is } \\
\text { required to serve } \\
\text { the customers }\end{array}$ \\
\hline
\end{tabular}

\subsubsection{Overall Architecture of the PSS Archetype Assessment Tool}

The tool for PSS archetype assessment comprises three parts: A readiness assessment (I), a vision assessment (II), and a gap analysis, based on a comparison of the readiness and the vision (III). The prototype of the tool was developed in Microsoft Excel and is available for download from the Technical University of Denmark repository (https: / / data.dtu.dk/s / 6ac1f4cf30b5bb05a4a7?file=26424854 (accessed on 10 February 2021)).

I-Readiness assessment

The readiness assessment consists of 30 questions, with three questions for each of the 10 factors for PSS archetype selection. The questions focus on the current business model of the company. Hence, the answers should not yet take into account future organisational aims or plans.

The assessment is designed to be conducted collaboratively in a multidisciplinary team, as it is important to discuss and reach consensus for the individual parts to build a common understanding of PSS across the team. To avoid bias from the participants, the questions in the assessment are mixed and sorted into five categories. The answers are given on a scale from one to six. Figure 2 illustrates an example of the first three questions in the tool. The complete list with the 30 questions is presented in the tool, which is available for download at https: / / data.dtu.dk/ s / 6ac1f4cf30b5bb05a4a7?file=26424854, (accessed on 10 February 2021).

Product same need?

Yes, the product is designed
for each individual customer
The product is new and
revolutionising compared to
similar products in the
No / To a low extend

Figure 2. Example of questions in the readiness assessment of the tool.

A tab called "2.1 Results" in the assessment tool displays the results of the assessment, summarised as a graph mapped according to the 10 factors leading to certain types of PSS (Figure 3). The graph indicates the corresponding PSS archetypes (i.e., vertical axis) according to the readiness level of each organisational factor (i.e., horizontal axis). The resulting score for each of the 10 factors is based on the mean value of the scores for the 3 questions related to each particular factor. The vertical scale of the graph is divided 
equally in 3, meaning that a resulting score of $<2$ corresponds to a product-oriented PSS, a score of $2-4$ corresponds to a use-oriented PSS, while a score of $>4$ corresponds to a result-oriented PSS.

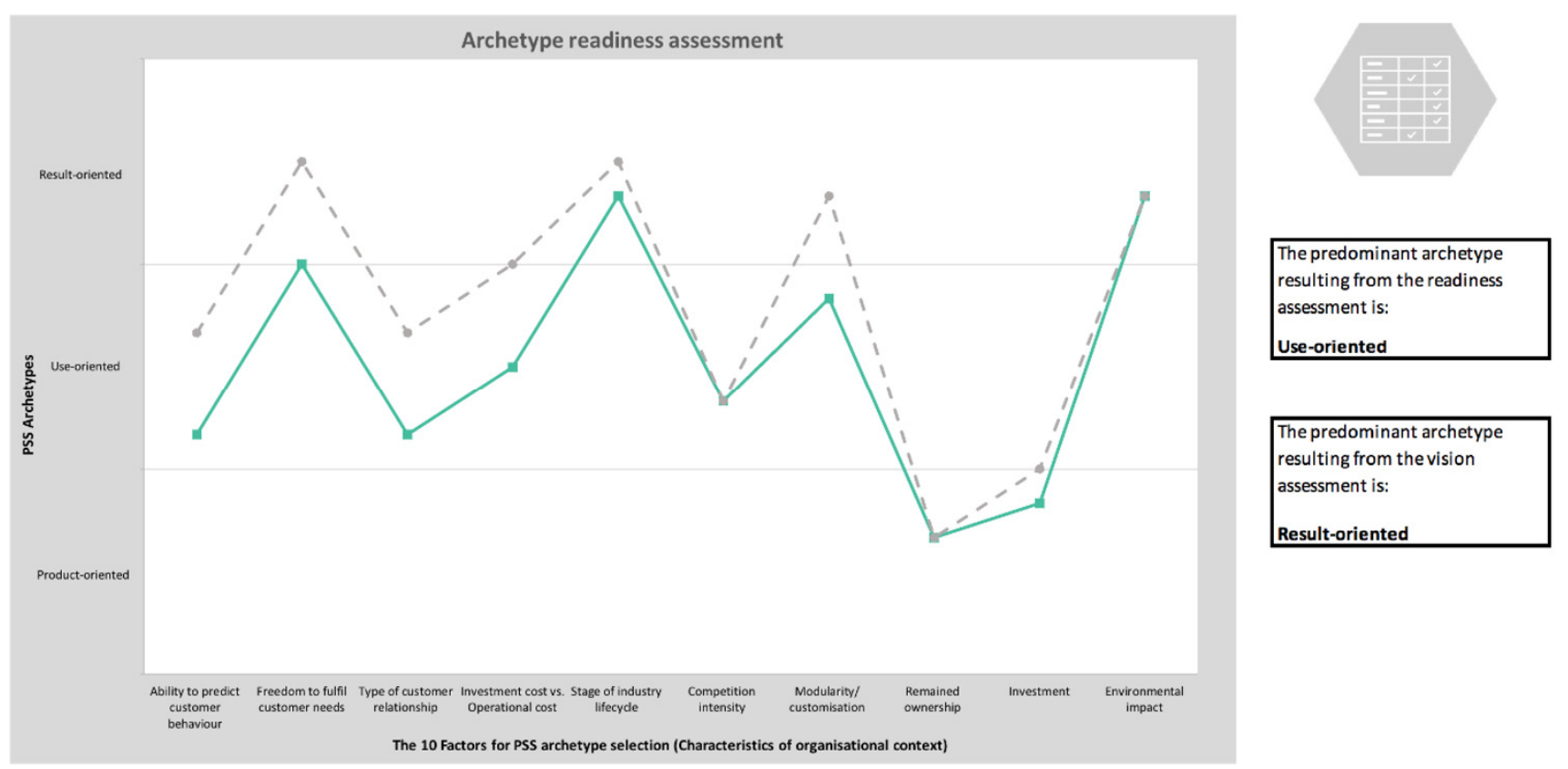

Figure 3. Results from the readiness assessment and the vision assessment forming the baseline for the comparison. Turquoise $=$ current readiness, and grey $=$ vision .

For some assessments, the results might indicate one clear archetype-i.e., all of the 10 factors point to the same archetype. However, in most cases, the resulting readiness related to different organisational factors will be leading to different archetypes, as is the case in Figure 3 (continuous turquoise line).

For the assessment in Figure 3, the readiness for most of the factors point towards a use-oriented PSS. However, if this company decides to proceed with the implementation of a use-oriented PSS, it will need to enhance their readiness in "remained ownership" and "willingness for investment". The readiness for "remained ownership" could be enhanced by preparing the organisation to keep responsibility and high service level beyond the point of sales, e.g., by setting up service and maintenance departments; preparing the organisation to deal with the end-of-use strategies for the different parts of the product (e.g., reuse, refurbish, recycle); exploring new continuous revenue mechanisms and schemes to enable extended customer relationship (e.g., subscription, x-as-a-service (XaaS)). Moreover, a convincing and comprehensive business case analysis, along with an indication of the market potential and acceptance, shall be considered to enhance the readiness of the organisation to investment in the PSS business model.

\section{II-Vision assessment}

The next part of the archetype assessment is the vision assessment, which takes into account the company's vision for the future. The vision assessment builds on the same 30 questions available in the readiness assessment, but rephrased to stimulate participants to focus on the perspective of their envisaged future, without taking into account the current stage (Figure 3, dashed grey line).

\section{III-Comparison: Gap analysis between the vision and the readiness}

After completing the vision assessment, the participants can proceed to the final tab of the tool, called "2.3 Comparison". The results of the readiness assessment and the vision assessment are analysed concurrently, with a graph combining the two assessments, one indicating the current readiness, and one indicating the company's vision (see Figure 3). This 
allows the participants to compare and reflect upon the results. To initiate the comparison, the participants shall reflect upon:

- What is the PSS archetype indicated by the readiness assessment vs. the one indicated by the vision assessment? Do they indicate the same archetype?

- Which organisational factors require readiness enhancement to suit the envisioned PSS archetype?

In cases where the readiness and vision assessments clearly indicate the same PSS archetype, that archetype is selected for the subsequent steps of the method. However, in cases where the two assessments point to different PSS archetypes, it is recommended to choose the one indicated by the readiness and adjust the business model according to the vision in the subsequent steps. For example, in the case shown in Figure 3, the two assessments indicate different PSS archetypes, but since the readiness assessment points mostly to the use-oriented PSS, this is taken as a starting point for the further PSS planning.

\subsection{Method for Archetype-Based PSS Development}

The method for archetype-based PSS development is a step-by-step approach comprising five steps for guiding the selection and specification of a PSS business model. The method was developed to support the application of the tool for PSS archetype assessment, thus including steps that occur prior to and after the selection of a PSS archetype. The tool for PSS archetype assessment is integrated as the second step of the method (Figure 4).

1.

ANALYSIS OF CURRENT BUSINESS MODEL

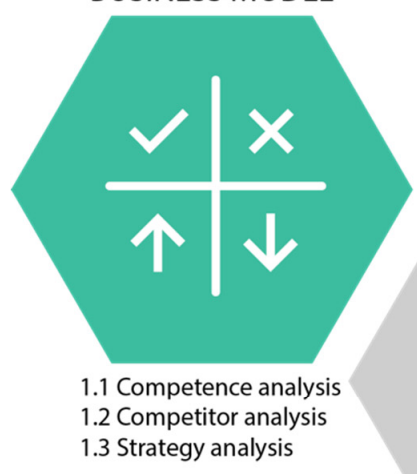

3. UNDERSTANDING THE ARCHE TYPE

\section{2.} PSS ARCHETYPE ASSESSMENT

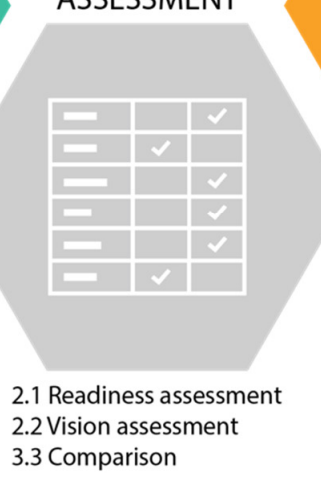

Figure 4. The five steps of the method.

In the following subsection, the final version of the method is presented, including the improvements identified throughout the evaluation in Descriptive Study 2.

\section{How to use it?}

The method is applicable to the initial stages of PSS development and focused on a strategic business level. It can be applied whenever a need for servitisation and business model innovation has been identified in the organisation, and no extensive prior knowledge about PSS business models is required for its application.

The method is applied in a workshop-based approach, for which the company should engage a multidisciplinary team representing different parts of the organisation, e.g., product experts, sales and operation managers, marketing and business development. The workshop should be facilitated by one of the participants, preferably one that is relatively familiar with PSS and business development. It can either be facilitated as one long 
workshop comprising all five steps or two-three workshops including one or more of the steps. The steps of the method should be followed collaboratively to facilitate discussions and consensus amongst the group of participants.

Figure 4 provides an overview of the five steps of the method. Templates to guide the steps of the method are available in the Supplementary Materials File S1.

\section{Step 1-Analysis of current business model}

The goal of step 1 is to analyse the existing business model of the company to establish a common foundation for the archetype assessment. Altogether, the three parts of Step 1 are estimated to last approximately one hour.

\section{Step 1.1. Competence analysis}

The competence analysis aims at assessing the company's strengths, weaknesses, threats, and opportunities based on their current business model. A SWOT framework is applied for this analysis. Some participants might already be familiar with this type of analysis, however, repeating the exercise with the multidisciplinary group representing different parts of the organisation helps to establish a common foundation.

\section{Step 1.2. Competitor analysis}

The competitor analysis builds upon the competence analysis with the goal of examining the strengths and weaknesses of the major competitors and at least one substitute product. The analysis applies a framework similar to the SWOT framework, to enable a comparison to the company's own strengths and weaknesses discussed in Step 1.1.

\section{Step 1.3. Strategy analysis}

The goal of the strategy analysis is to reflect on the company's vision, mission, values, and goals for the development of PSS-based business models. This serves to establish a clear and consensual focus amongst the group before initiating the actual business model development.

The output of Step 1 is an overview of the critical aspects of the current business model to guide the archetype assessment in Step 2. Furthermore, a common foundation is established amongst the team, creating the foundation to work in the subsequent steps of the method.

\section{Step 2-PSS archetype assessment}

The analysis of the current business model conducted in Step 1 serves as input for the PSS archetype assessment tool, which should be used to conduct the assessment in Step 2. It is recommended to reserve one to two hours for this step.

Step 2.1. Readiness assessment (see Section 3.1.3)

Step 2.2. Vision assessment (see Section 3.1.3)

Step 2.3. Comparison (see Section 3.1.3)

The output of Step 2 is a selected PSS archetype resulting from the use of the tool, which forms the basis for the subsequent steps of the method, when the PSS archetype is further specified according to the particular case and company.

\section{Step 3-Understanding the archetype and its implications for the current business model}

The goal of Step 3 is to understand the selected PSS archetype and the required changes to the current business model of the company.

\section{Step 3.1. Study the PSS business model concept based on the selected PSS archetype}

As an introduction to Step 3, the participants are introduced to the business model concept behind the selected PSS archetype. This is presented through a business model canvas (BMC) [61] summarizing the main characteristics of the given PSS archetype. The business model canvas (BMC) is applied for this purpose, due to its ability to offer a holistic perspective of a given business model $[43,62]$, while also being widely recognized and 
applied in industry, and therefore also expected to be familiar amongst the target users of the method.

\section{Step 3.2. Identify critical changes required for the implementation of the given PSS archetype}

The BMC described above is used to summarise and highlight the critical changes required for the implementation of the given PSS archetype. The BMC provides basis for a discussion amongst the team members.

As an output of Step 3, the team will have extended their knowledge about the selected PSS archetype and the required changes for the implementation of such a business model. Based on these learnings, there might be changes that are considered too drastic or inappropriate for the specific context, and these will provide input for Step 4, e.g., if the product is customised to an extent that it cannot later be used by another customer, it might not make sense for the provider to maintain product ownership.

\section{Step 4-Specification of a unique business model}

The goal of Step 4 is to specify a unique business model for the future based on the selected PSS. The input for the selection should be based on the readiness and vision assessments that emerged in Step 2 and the implied changes discussed in Step 3.

\section{Step 4.1. Specify a PSS business model and its strategic characteristics}

This step is supported by the PSS morphology shown in Figure 5, adapted from the morphology presented by [2]. The PSS morphology presents eight strategic characteristics that form some of the building blocks of a PSS business model and its variations across the different PSS archetypes, which can be combined in numerous ways to describe a PSS concept at a high level. The variations, typically corresponding to the selected PSS archetype, are indicated in the morphology. Ultimately, the team is responsible to create their own hybrid business model by combining characteristics across different archetypes. They do that by selecting a variation for each of the strategic characteristics in the morphology.

The output of this step will be a strategic specification of a PSS-based business model, elaborated to the available/possible level of detail for the company. Characteristics that cannot be specified yet are addressed during the further development in Step 5.

\section{Step 5-Planning further development}

The goal of Step 5 is to summarise all the previous steps into a roadmap for the further development of the PSS business model. Hence, it leads the team from the initial strategic level of development into the more detailed PSS development and ultimately towards implementation.

\section{Step 5.1. Summarise actions and changes to the business model identified through Steps 2-4}

In this step, the actions emerging from all the previous steps are to be summarized into a plan for the further development. To make sure that all the Steps 1-4 are summarized into actions, a checklist for reflection of each step is provided (see Supplementary Materials).

\section{Step 5.2. Draw a roadmap for the further development of the PSS business model}

The list of actions are then drawn into a roadmap (see template in the Supplementary Materials), providing a timeline for the further development. It includes the responsible stakeholder/department and planned milestones.

The output of Step 5 is a plan for the further development and implementation of the PSS business model.

The overall output of the method comprises: (1) A strategic definition of a PSS business model that is specified according to the company and its current business model, and (2) a plan for the further development of the PSS-oriented business model. 


\section{Use-Oriented PSS}

\begin{tabular}{|c|c|c|c|c|c|}
\hline $\begin{array}{c}\text { Strategic } \\
\text { Characteristics }\end{array}$ & Variation A & Variation B & Variation C & Variation D & Variation E \\
\hline $\begin{array}{l}\text { Benefit is orie- } \\
\text { nted towards: }\end{array}$ & $\begin{array}{l}\text { Ownership of the } \\
\text { physical product }\end{array}$ & $\begin{array}{l}\text { Use of } \\
\text { the product }\end{array}$ & $\begin{array}{l}\text { Results of the use } \\
\text { of the product }\end{array}$ & $\begin{array}{l}\text { Consumption } \\
\text { of the product }\end{array}$ & \\
\hline $\begin{array}{l}\text { Transfer of } \\
\text { ownership }\end{array}$ & After delivery & $\begin{array}{c}\text { After } \\
\text { installation }\end{array}$ & $\begin{array}{l}\text { Returns to company } \\
\text { at end of life }\end{array}$ & $\begin{array}{l}\text { Is never transferred - owned by } \\
\text { the company throughout its life }\end{array}$ & $\ldots$ \\
\hline $\begin{array}{l}\text { Responsibility } \\
\text { during use }\end{array}$ & $\begin{array}{l}\text { Customer has } \\
\text { full responsibility }\end{array}$ & $\begin{array}{l}\text { Company is responsible } \\
\text { for installing }\end{array}$ & $\begin{array}{l}\text { Company installs, } \\
\text { maintains and takes back }\end{array}$ & $\begin{array}{l}\text { Company has full responsibility } \\
\text { for the use of the product }\end{array}$ & \\
\hline $\begin{array}{l}\text { Management of } \\
\text { life cycle activities }\end{array}$ & $\begin{array}{l}\text { Company manages all before } \\
\text { and included installation }\end{array}$ & $\begin{array}{l}\text { Company manages the } \\
\text { operation and maintenance }\end{array}$ & $\begin{array}{l}\text { Company manages } \\
\text { upgrading }\end{array}$ & $\begin{array}{l}\text { Company manages } \\
\text { continuous improvements }\end{array}$ & $\ldots$ \\
\hline $\begin{array}{l}\text { Expansion } \\
\text { of benefits }\end{array}$ & $\begin{array}{c}\text { Core } \\
\text { benefit alone }\end{array}$ & $\begin{array}{l}\text { Multiple benefits } \\
\text { aggregated together }\end{array}$ & $\begin{array}{l}\text { Multiple benefits integrated } \\
\text { with each other }\end{array}$ & & \\
\hline $\begin{array}{l}\text { Economical } \\
\text { value based on }\end{array}$ & Transfer of ownership & $\begin{array}{l}\text { Value based } \\
\text { on per use }\end{array}$ & $\begin{array}{l}\text { Value of the } \\
\text { management activities }\end{array}$ & $\begin{array}{l}\text { Value of taking } \\
\text { responsibility of the use }\end{array}$ & $\begin{array}{l}\text { Value of the } \\
\text { result of use }\end{array}$ \\
\hline $\begin{array}{l}\text { Level of } \\
\text { digitalisation }\end{array}$ & $\begin{array}{c}\text { Manual service: } \\
\text { Digital technology used } \\
\text { for management at most }\end{array}$ & $\begin{array}{l}\text { Digital service: } \\
\text { Digital technology used } \\
\text { to provide service. }\end{array}$ & $\begin{array}{l}\text { Industri } 4.0 \text { service: } \\
\text { Process and customer related } \\
\text { digital service }\end{array}$ & $\cdots$ & $\ldots$ \\
\hline
\end{tabular}

Figure 5. PSS morphology adapted from [2].

\section{Practical Application and Evaluation of the Tool and Method for PSS Development Based on Archetype Assessment}

The evaluation of the method and accompanying tool for PSS development based on archetype assessment is presented in three sections. First, the evaluation performed with a manufacturing company is introduced in Section 4.1 (i.e., result of Descriptive Study 2). Then, the incorporation of improvement opportunities and the proposal of a final version for the method and tool are presented in Section 4.2 (i.e., results of Prescriptive Study 2). Finally, the evaluation of the final version of the method and tool by Master students from an Engineering PSS Development course is explained in Section 4.3 (i.e., results of Descriptive Study 3).

\subsection{Evaluation with a Manufacturing Company}

The evaluation of the applicability and usefulness of the method and tool was conducted with a team of four employees from the case company with different professional backgrounds. All participants were engaged with business development as part of their daily work. The evaluation was conducted through three workshops with the following objectives:

- Workshop 1: To analyse the current business model of the business unit (step 1);

- Workshop 2: To identify a PSS archetype using the assessment tool (steps 2-3);

- Workshop 3: To specify a unique business model and plan further development (steps 4-5).

Each workshop lasted approximately one-and-a-half hour.

In the first workshop, the proposed steps served to facilitate valuable and relevant discussions about the strengths and weaknesses of the current business model, the strengths 
of the competitors and the strategy for the future. The team from the case company showed great motivation for the analysis and seemed to work well together, discussing and building upon each other's inputs. Even though all participants were already familiar with the SWOT framework, the focus on service and the fact that they had not previously used the framework collaboratively created a valuable discussion for the competence analysis (Step 1.1). The same aspects were observed during the competitor analysis (Step 1.2). During the strategy analysis (Step 1.3), the participants commented that the proposed template was too generic and had to be adapted or tailored to their context, since the overall mission and values in their case would be inherited from the corporate strategy, rather than defined at the level of the business unit. However, by narrowing in on the perspective of their business unit and their strategy in relation to services, a valuable discussion was established and the team agreed on an overall vision for their service strategy.

In the second workshop, the participants used the tool for PSS archetype assessment (Step 2 in Figure 4). The readiness assessment (Step 2.1) encouraged the participants to reflect upon whether they were actually performing as well as they expected. For example, one of the participants raised a question to the group: "Do we actually know our customers well enough to be able to predict their activity with regards to maintenance and so on?" Furthermore, the scale of options provided in the tool for each question of the readiness assessment served to guide decision-making while enhancing the participants' vocabulary and articulation on PSS development. For example, it was possible to observe that some words and terminology were directly adopted from the tool by the participants during their discussions. During the readiness assessment, the participants required further explanations from the researchers about the 10 factors to be able to discuss and reflect upon the results. The vision assessment (Step 2.2) helped the team to reconsider the PSS archetype that they would otherwise have chosen and to explore alternatives. As a conclusion of the second workshop, and on the basis on the comparison carried out in Step 2.3, a use-oriented PSS archetype was selected, driven mainly by the readiness assessment discussions.

As preparation for the third workshop, the team was asked to study the business model canvas (Step 3 in Figure 4) describing a use-oriented PSS archetype as selected by them in Workshop 2. During the third workshop, a PSS business model was specified using the morphology (Step 4 in Figure 4 ) with the use-oriented PSS as a starting point. Despite difficulties observed during the use of the morphology, the participants specified all strategic characteristics for the PSS. The application of the morphology served to further enhance the team's articulation about how a PSS business model could work for their company. The business model specified at this stage started from the use-oriented PSS selected through the tool, but ended up as a hybrid, combining characteristics from all three PSS archetypes. In addition, during the third workshop, a list of activities for improving the company's readiness for PSS was summarised based on the learnings from the first four steps of the method (Steps 1 to 4 in Figure 4). The list was the backbone for the creation of a roadmap for further development of the PSS (Step 5 in Figure 4). Guiding questions included in the template to support the roadmap development became redundant as the participants summarised all the previous steps without the need for guiding questions. The team had many ideas and agreed on several future activities for the PSS development. Complementarily to that, they identified that the development of a PSS business model would require additional support from the top management and a dedicated team for the purpose.

In the final session, the participants were asked to answer to a structured written evaluation form about the method, which was complemented by an oral evaluation through discussions. Overall, the evaluation revealed that the method served as a framework that can provide a structured approach for exploring the opportunities of PSS business models within a manufacturing company. The shared exploration of the new opportunities within the workshop setup promoted useful and structured discussions (i.e., a clear link between the different steps) and ensured documentation of the process. Moreover, the method 
served to challenge the status-quo and common practices of the company by enhancing the articulation of participants on PSS-oriented business model innovation and pushing them to consider PSS opportunities that they would otherwise not have seen as relevant. Additionally, the method worked well with participants with limited knowledge of PSS development. The participants found the method easy to use, especially the steps applying well-known frameworks, which the users were already familiar with (e.g., SWOT and the business model canvas). Only the morphology posed additional difficulties to the users; however, they were able to apply it after an introduction to the framework.

Despite the positive uptake of the method by the manufacturing company, improvement opportunities were recommended. In this first version of the tool that was evaluated with the case company, the vision assessment was conducted with the support of nine distinct PSS example cases. The example cases were individually presented for the team, and they rated each of the cases on a scale of: (1) How realistic it would be to implement a similar business model for their product; and (2) how innovative such business model would be in their market. Based on the highest ranked cases, a potential PSS archetype would be recommended to the company. The evaluation provided evidence that the vision assessment was confusing to some participants, and they faced difficulties to rate cases. Participants associated these difficulties with their limited knowledge about PSS business models or the fact that they were not necessarily acquainted with cases falling outside the market or product scope of their own company. Furthermore, some participants claimed that the vision assessment was not aligned with the other steps and had no link with the 10 factors used for PSS archetype assessment. Moreover, an explanation of the 10 factors for PSS archetype assessment should be included in the tool to enable the participants to interpret the results without the help from a facilitator.

\subsection{Improvement of the Tool and Method}

In this phase, a second version for the method and tool was developed on the basis of the improvement opportunities identified during the evaluation with the manufacturing company. One major adaptation was made in the tool for PSS archetype assessment. The vision assessment went through several iterations, and the new version was developed, based on the 10 factors for PSS archetype assessment. This aimed at enhancing the relevance and strengthening the link between the readiness and the vision assessment. The new version of the tool as described in Section 3 uses the same format of the 30 questions both for the readiness and the vision assessment. Maintaining a similar logic for the vision assessment and the readiness assessment enhances the participants' understanding of the 10 factors and facilitates the comparison in Step 2.3, since the two graphs can be directly compared. Moreover, minor adaptations were made based on the evaluation with the case company. In the result sections of the readiness and vision assessment, an explanation of the 10 factors for PSS archetype selection was added in order to support the interpretation and enhance the dialogue about the factors amongst the participants. Furthermore, modifications were applied to the phrasing of the questions for the readiness and vision assessments to facilitate the interpretation and dialogue among participants during the discussions.

\subsection{Evaluation of the Final Version of the Tool and Method with Master Students from a PSS Design Course}

In Descriptive Study 3, the improved version of the method was evaluated with a group of 60 engineering master students participating in a course on 'Development and Operation of Product-Service Systems' at the Technical University of Denmark. The evaluation was conducted as a 2-h workshop session with a primary focus on step 2 of the method-i.e., the improved tool for PSS archetype assessment.

The students were divided into 13 groups working on different projects for further development of an existing PSS under the theme "sharing solutions". Prior to the workshop, the groups had analysed the existing business model of their respective PSS for four weeks, thus Step 1 of the method was considered already concluded. The PSS archetype 
assessment (i.e., Step 2) served to scope their PSS development in the initial stages of a development process towards improved or new PSS business models. As opposed to the evaluation conducted with the manufacturing company, the participants in this evaluation were trained about PSS business models and the corresponding theory. Furthermore, they were working with existing PSS business models primarily based on the use-oriented archetype, whereas the manufacturing company started from a traditional product-oriented business model.

In the beginning of the workshop the participants were introduced to the tool, its purpose, and the three PSS archetypes. As they had already analysed the strengths and weaknesses of the current business model, they started directly in the readiness assessment (Step 2.1), which enabled rich discussions in the groups. After $30 \mathrm{~min}$ of discussions focused on the readiness assessments, the results were reviewed and discussed in plenary. Then, the new version of the vision assessment was introduced, and the participants completed the 30 questions again, however, faster since they were familiar with the format. After the completion of the vision assessment, the reflection of the comparison was done in plenary with some of the groups presenting their results for collaborative reflection.

Based on this evaluation, evidence was gathered to show that Step 2 of the method and mainly the tool for PSS archetype assessment served as a framework to stage discussions on the relevant topics for scoping PSS development. The students considered the method as an intuitive and tangible approach for initiating PSS development in a structured way. Through the readiness assessment, the tool enabled students to obtain an overview of the current situation of the company, the as-is scenario, while being able to compare it directly to the envisaged state (i.e., the to-be scenario) and foresee specific areas for improvement. The interpretation of the results for the participants was smoother than on the previous tool, due to the improvements of the vision assessment. Moreover, the comparison graph of the readiness versus vision assessments served as a visual overview of the current and future scenario, forming a common ground for discussions.

Shortcomings in the archetype assessment tool were observed for the context of businesses that were already applying a PSS business model. In particular, the questions in the readiness and vision assessments were not all suitable, since they assumed a productoriented business model as the starting point, whereas some of the analysed companies were already service-based and did not own an actual product. Furthermore, it was observed that the readiness assessment can be time consuming due to the amount of questions and the importance of discussing each one of the questions. In the workshop, the groups had a time limit of $30 \mathrm{~min}$ for the readiness assessment, which was not enough for the completion of the discussions. On the other hand, the time limit was useful to keep the pace and set a deadline for the discussions. The full potential of the archetype assessment and the extent to which it facilitates the improvement of a company's readiness for a certain PSS archetype can only be unleashed if the participants explore the 10 factors in depth and understand their respective impacts on the existing business model(s).

\section{Discussion}

This section summarises the key findings that emerged during the development of the tool and method for PSS archetype assessment, and discusses them in light of previous literature.

The evaluation of the method and tool by industry practitioners and Design Engineering students confirmed its applicability in supporting the initial stage of PSS development, specifically, the scoping of new PSS business models through the selection and modification of PSS archetypes. In particular, the archetypes enabled effective knowledge transfer and contextualisation for companies or participants that had limited experience and skills required for PSS development, thus answering the call by Richter et al. [37]. This observation is consistent with findings presented by Barquet et al. [55] and Pieroni et al. [46], which also applied archetypes to support manufacturing companies from different sectors in the early stages of business model design for PSS or circular economy. 
Table 3 presents a comparative analysis that indicates how the method presented in this paper fulfils gaps in relation to a selected range of PSS development and servitisation methods, by integrating characteristics such as: (i) Coverage of PSS exploration stage; (ii) support for scoping of PSS development; (iii) application and recommendation of PSS archetypes; (iv) combination of servitisation and PSS development; (v) applicability for users across background and level of experience; (vi) application in industry; and (vii) applicability for pure product-oriented companies.

Table 3. Comparison of the developed method with available PSS development and servitisation methods. $\boldsymbol{V}$ indicates a clear implementation of the characteristics, whereas $(\boldsymbol{})$ indicates a more indirect implementation.

\begin{tabular}{|c|c|c|c|c|c|c|c|}
\hline $\begin{array}{l}\text { Models and } \\
\text { Approaches } \\
\text { for PSS } \\
\text { Development }\end{array}$ & $\begin{array}{c}\text { Coverage of } \\
\text { PSS } \\
\text { Exploration (i) }\end{array}$ & $\begin{array}{c}\text { Supports } \\
\text { Scoping of } \\
\text { PSS } \\
\text { Development } \\
\text { (ii) }\end{array}$ & $\begin{array}{c}\text { Recommendation } \\
\text { of PSS } \\
\text { Achetypes (iii) }\end{array}$ & $\begin{array}{l}\text { Combining } \\
\text { Servitisation } \\
\text { and PSS } \\
\text { Development } \\
\text { (iv) }\end{array}$ & $\begin{array}{l}\text { Aplicability } \\
\text { for Users } \\
\text { Across } \\
\text { Background } \\
\text { and Level } \\
\text { Experience (v) }\end{array}$ & $\begin{array}{c}\text { Application } \\
\text { in Industry } \\
\text { (vi) }\end{array}$ & $\begin{array}{c}\text { Applicability } \\
\text { for Pure } \\
\text { Product } \\
\text { Oriented } \\
\text { Companies } \\
\text { (vii) }\end{array}$ \\
\hline $\begin{array}{c}\text { Snakes and } \\
\text { ladders in } \\
\text { servitisation } \\
\text { [30] }\end{array}$ & $\checkmark$ & & & & & $\checkmark$ & $\checkmark$ \\
\hline $\begin{array}{l}\text { PSS transition } \\
\text { framework [40] }\end{array}$ & & $(\boldsymbol{V})$ & $(\boldsymbol{V})$ & & $v$ & & $v$ \\
\hline $\begin{array}{l}\text { Method to } \\
\text { create } \\
\text { proposals for } \\
\text { PSS business } \\
\text { models [41] }\end{array}$ & $(\boldsymbol{\sim})$ & $\checkmark$ & $(\boldsymbol{V})$ & & $\boldsymbol{v}$ & & \\
\hline $\begin{array}{c}\text { Business } \\
\text { model } \\
\text { innovation } \\
\text { process for } \\
\text { servitising } \\
\text { industrial } \\
\text { firms [42] }\end{array}$ & & & & & $\checkmark$ & $\boldsymbol{v}$ & $(\boldsymbol{V})$ \\
\hline $\begin{array}{l}\text { Product service } \\
\text { system } \\
\text { transition } \\
\text { method [44] }\end{array}$ & & & $\checkmark$ & & & $v$ & \\
\hline $\begin{array}{l}\text { PSS business } \\
\text { models (BMs) } \\
\text { framework [43] }\end{array}$ & $(\boldsymbol{V})$ & & & $(\boldsymbol{\sim})$ & $\boldsymbol{v}$ & $\checkmark$ & $\checkmark$ \\
\hline $\begin{array}{l}\text { Method for } \\
\text { archetype- } \\
\text { based PSS } \\
\text { development } \\
\text { (Presented in } \\
\text { this research) }\end{array}$ & $\checkmark$ & $v$ & $\checkmark$ & $v$ & $v$ & $\checkmark$ & $v$ \\
\hline
\end{tabular}

Regarding the scope of applicability, the tool and method were built based on the assumption that the company using it seeks servitisation and starts from a pure productoriented business model, similar to many of the other studied methods (Table 3). This scope was confirmed during the second evaluation round, as the tool was limited in supporting existing PSS companies. Further work should address how the tool can be adapted for existing PSS companies for scoping the development of PSS business models either in the direction of servitisation or productisation (i.e., de-servitisation), depending on the desired strategy [32]. An example of a method addressing these existing PSS companies is the one developed by Chiu et al. [44] (Table 3).

When compared to other approaches in literature, a strength of using the method for archetype-based PSS development (presented in this research) provides a systematic approach for exploring the concept of PSS, and thus provides guidance in identifying the 
best suiting PSS archetype according to the current readiness, while indicating factors that require improvement for enhanced readiness. The key contributions of this article and the proposed method are the set of 10 factors and their application logic presented to guide the selection of the best suiting PSS archetype for companies. The use of these factors enabled a well-informed choice by the business developers in the case company and the Design Engineering students, even when they had limited or no knowledge about PSS. In particular, the 10 factors contribute to offering proactive advice to companies by: (i) Identifying current readiness of manufacturing companies via strategic characteristics conducive to different types of PSS; and (ii) translating them into the envisaged future scenario for the new PSS business models. The development of the 10 factors and their application logic in the tool advance current literature and answer calls for providing support to companies with prescriptive approaches, especially in the selection of archetypes or choices for which business models to adopt $[46,63]$. The prescriptive use of the PSS archetypes by companies (unleashed by the 10 factors and their selection logic) integrates knowledge from existing PSS business models, enabling its application by companies with little or no experience with PSS, serving as a stepping stone for further modification and contextualisation that can trigger the creation of innovative PSS business models. This effect can also be seen in the methods by Pieroni et al. [40], Barquet et al. [41], and Chiu et al. [44], which also apply PSS archetypes, although in a more exploratory way, without explicit recommendations to companies (Table 3).

Another strength of the proposed approach, also present in the methods developed by Pieroni et al. [40], Adrodegari et al. [42,43], and Barquet et al. [41] (Table 3), is its broad applicability for users coming from different backgrounds and with different levels of experience with PSS business models, as indicated by the different groups of users in the evaluation. By integrating familiar frameworks for business model innovation, as the business model canvas and the SWOT framework, the users get to be "on home ground" while building a common understanding of PSS and getting started on PSS development. Furthermore, the application of the method in the case company points to its potential to enhance the articulation of collaborators on PSS and encourage servitisation in organisations. An overarching servitisation approach aligned with the systematic PSS development activities seemed to have promoted synergies and triggered awareness for the strategic importance of PSS development within the organization, as previously noted in the literature [16]. The combination of servitisation and PSS development, not seen in other of the studied methods (Table 3) and the prescriptive approach for the use of PSS archetypes stimulated valuable discussions regarding the PSS opportunities, triggering the users' mindsets about a future PSS business model. For example, before working with the method, the team of business developers were not acquainted with the concept or sceptic about its applicability in practice. However, they changed their opinion after working with the method, and left the sessions convinced about the potential of servitisation, which triggered them to take the results to the management team with the aim to establish a project to develop and implement the selected PSS in their organisation.

Finally, the resulting PSS business models that emerged from the application of the method and tool by the company and Design Engineering students pointed to their potential in influencing the development of business models with conducive characteristics for enhanced circularity and/or sustainability. As an example, the use-oriented business model developed by the company included product takeback and refurbishment. However, the actual potential of these business models to lead to absolute resource decoupling and enhanced social impact need to be further assessed by proper quantitative approaches, such as life cycle modelling as suggested by Fargnoli et al. [25] and Kjaer et al. [23,64].

\section{Conclusions and Next Steps}

In practice, the proposed method and tool represent a concrete proposal for a hands-on approach for manufacturing companies to get started with PSS development and enhance 
business model innovation with a systematic and strategic perspective while triggering collaboration across departments. The main research contributions of this paper include:

a. A proposal for a method and accompanying tool to guide manufacturing companies in initiating the transition from a product-oriented business models to PSS-oriented business models;

b. a list of 10 factors indicating strategic organisational characteristics that can be conducive to the development of different types of PSS business models. This guides the PSS archetype assessment and works as the core logic of the method and tool;

c. an integration of existing tools from servitisation and PSS development bodies of knowledge, answering the call for research by Baines et al. [29].

The outcome of applying the proposed approach is a PSS business model specified at the strategic business level, which serves as way to approach PSS development and scope the further work. Further work could be done to provide additional guidance for the subsequent PSS development to be conducted upon completion of the method, including user studies and market research. This guidance might, as well as the current method, integrate existing PSS development frameworks, e.g., the framework provided by PROTEUS [2]; and point to relevant tools depending on the selected PSS archetype.

For validation of the tool, further work should be done to confirm the 10 factors for PSS archetype selection in different contexts. This could be done by evaluating the factors with companies that have already completed and implemented a PSS business model based on a specific archetype, either as a qualitative analysis building upon interviews with the companies or as a quantitative analysis of the effects of the factors on the type of PSS offered by manufacturing companies similar to the one conducted by Mastrogiacomo et al. [65]. Through such analysis, it might also be possible to identify the relative importance of the factors, since the current version of the tool assumes equal importance to all of them. Moreover, the tool and the overall method could be further strengthened by conducting further evaluations with a wider set of manufacturing companies from different sectors. Further limitations of this research are related to the techniques applied for the literature review. The field of research related to PSS and business model innovation is rapidly developing, and from recent and future publications, new archetypes may appear, leading to a need for continuously updating the tool.

Supplementary Materials: The following are available online at https:/ /www.mdpi.com/2071-105 0/13/5/2592/s1, File S1: Templates for steps 1, 3, 4, 5.

Author Contributions: Conceptualization, T.B.F., D.C.A.P., and T.C.M.; methodology, T.B.F., D.C.A.P., and T.C.M.; software, T.B.F; validation, T.B.F., M.P.P.P., D.C.A.P., and T.C.M.; formal analysis, T.B.F.; investigation, T.B.F.; resources, D.C.A.P. and T.C.M.; data curation, T.B.F.; writing-original draft preparation, T.B.F. and M.P.P.P.; writing—review and editing, T.B.F., M.P.P.P., D.C.A.P., and T.C.M.; visualization, T.B.F. and M.P.P.P.; supervision, D.C.A.P. and T.C.M.; project administration, T.B.F. All authors have read and agreed to the published version of the manuscript.

Funding: This research received no external funding.

Acknowledgments: This article is an outcome of a master thesis project conducted for the Technical University of Denmark. We would like to thank the participating manufacturing company for the collaboration as well as the Engineering Design students from the course in Development and Operation of Product-Service Systems.

Conflicts of Interest: After the completion of the research, one of the authors has taken a position in the described case company, although in a different business unit than the one participating in this research, and with no influence on the further implementation of the developed PSS business model, or the further use of the tool and methodology. Throughout the research, the described case company had no role in the design of the study; in the analysis, or interpretation of data; in the writing of the manuscript; or in the decision to publish the results. 


\section{References}

1. Karmarkar, U.S.; Apte, U. Operations management in the information economy: Information products, processes, and chains. J. Oper. Manag. 2007, 25, 438-453. [CrossRef]

2. Finken, K.H.; McAloone, T.C.; Avlonitis, V.; Garcia i Mateu, A.; Andersen, J.A.B.; Mougaard, K.; Neugebauer, L.M.; Hsuan, J. PSS Tool Book; Technical University of Denmark: Copenhagen, Denmark, 2013.

3. Tukker, A.; Tischner, U. New Business for Old Europe; Greenleaf Publishing: Sheffield, UK, 2006.

4. Tukker, A. Eight types of product-service system: Eight ways to sustainability? Experiences from suspronet. Bus. Strateg. Environ. 2004, 13, 246-260. [CrossRef]

5. Mont, O. Drivers and barriers for shifting towards more service-oriented businesses: Analysis of the PSS field and contributions from Sweden. J. Sustain. Prod. Des. 2002, 2, 89-103. [CrossRef]

6. Haase, R.P.; Pigosso, D.C.A.; McAloone, T. Product/Service-System Origins and Trajectories: A Systematic Literature Review of PSS Definitions and their Characteristics. Procedia CIRP 2017, 64, 157-162. [CrossRef]

7. Baines, T.S.; Lightfoot, H.W.; Benedettini, O.; Kay, J.M. The servitization of manufacturing. J. Manuf. Technol. Manag. 2009, 20, 547-567. [CrossRef]

8. Rodrigo, R.; Willem, H.; Marko, K.; Jukka, S. Structuring servitization-related research. Int. J. Oper. Prod. Manag. 2018, 38, 350-371. [CrossRef]

9. Tukker, A. Product services for a resource-efficient and circular economy-A review. J. Clean. Prod. 2015, 97, 76-91. [CrossRef]

10. Reim, W.; Parida, V.; Örtqvist, D. Product-Service Systems (PSS) business models and tactics-A systematic literature review. J. Clean. Prod. 2015, 97, 61-75. [CrossRef]

11. Matzen, D. A Systematic Apporach to Service Oriented Product Development; Technical University of Denmark: Copenhagen, Denmark, 2009.

12. Tan, A.R. Service-Oriented Product Development Strategies; DTU Management: Copenhagen, Denmark, 2010.

13. Mont, O.K. Clarifying the concept of product-service system. J. Clean. Prod. 2002, 10, 237-245. [CrossRef]

14. Pigosso, D.C.A.; McAloone, T.C. Supporting the Development of Environmentally Sustainable PSS by Means of the Ecodesign Maturity Model. Procedia CIRP 2015, 30, 173-178. [CrossRef]

15. Bech, N.M.; Birkved, M.; Charnley, F.; Laumann Kjaer, L.; Pigosso, D.C.A.; Hauschild, M.Z.; McAloone, T.C.; Moreno, M. Evaluating the Environmental Performance of a Product/Service-System Business Model for Merino Wool Next-to-Skin Garments: The Case of Armadillo Merino ${ }^{\circledR}$. Sustainability 2019, 11, 5854. [CrossRef]

16. Pieroni, M.P.P.; McAloone, T.C.; Pigosso, D.C.A. Configuring New Business Models for Circular Economy through ProductService Systems. Sustainability 2019, 11, 3727. [CrossRef]

17. Blomsma, F.; Kjaer, L.; Pigosso, D.; McAloone, T.; Lloyd, S. Exploring Circular Strategy Combinations-Towards Understanding the Role of PSS. Procedia CIRP 2018, 69, 752-757. [CrossRef]

18. Fernandes, S.d.C.; Pigosso, D.C.A.; McAloone, T.C.; Rozenfeld, H. Towards product-service system oriented to circular economy: A systematic review of value proposition design approaches. J. Clean. Prod. 2020, 257, 120507. [CrossRef]

19. De Pádua Pieroni, M.; Blomsma, F.; McAloone, T.C.; Pigosso, D.C.A. Enabling circular strategies with different types of product/service-systems. Procedia CIRP 2018, 73, 179-184. [CrossRef]

20. Annarelli, A.; Battistella, C.; Nonino, F. Product service system: A conceptual framework from a systematic review. J. Clean. Prod. 2016, 139, 1011-1032. [CrossRef]

21. Yang, M.; Smart, P.; Kumar, M.; Jolly, M.; Evans, S. Product-service systems business models for circular supply chains. Prod. Plan. Control 2018, 29, 498-508. [CrossRef]

22. Bocken, N.; Olivetti, E.; Cullen, J.; Potting, J.; Lifset, R. Taking the Circularity to the Next Level: A Special Issue on the Circular Economy: Taking Circularity to the Next Level. J. Ind. Ecol. 2017, 21, 476-482. [CrossRef]

23. Kjær, L.; Pigosso, D.; Niero, M.; Bech, N.; McAloone, T. Product/Service-Systems for a Circular Economy: The Route to Decoupling Economic Growth from Resource Consumption? J. Ind. Ecol. 2018, 23, 22-35. [CrossRef]

24. Pigosso, D.C.A.; McAloone, T.C. Maturity-based approach for the development of environmentally sustainable product/servicesystems. CIRP J. Manuf. Sci. Technol. 2016, 15, 33-41. [CrossRef]

25. Fargnoli, M.; De Minicis, M.; Tronci, M. Product's life cycle modelling for eco-designing product-service systems. Proc. Int. Des. Conf. Des. 2012, DS 70, 869-878.

26. Bertoni, M. Multi-criteria decision making for sustainability and value assessment in early PSS design. Sustainability 2019, 11, 1952. [CrossRef]

27. Frank, A.G.; Mendes, G.H.S.; Ayala, N.F.; Ghezzi, A. Servitization and Industry 4.0 convergence in the digital transformation of product firms: A business model innovation perspective. Technol. Forecast. Soc. Chang. 2019, 141, 341-351. [CrossRef]

28. Kowalkowski, C.; Windahl, C.; Kindström, D.; Gebauer, H. What service transition? Rethinking established assumptions about manufacturers' service-led growth strategies. Ind. Mark. Manag. 2015, 45, 59-69. [CrossRef]

29. Baines, T.; Ziaee Bigdeli, A.; Bustinza, O.F.; Shi, V.G.; Baldwin, J.; Ridgway, K. Servitization: Revisiting the state-of-the-art and research priorities. Int. J. Oper. Prod. Manag. 2017, 37, 256-278. [CrossRef]

30. Andrews, D.; Dmitrijeva, J.; Bigdeli, A.Z.; Baines, T. Snakes and Ladders in Servitization: Using a Game to Capture Inhibitors and Enablers of Transformation. Res. Manag. 2018, 61, 37-47. [CrossRef] 
31. Kohtamäki, M.; Baines, T.; Rabetino, R.; Bigdeli, A.Z. Practices and Tools for Servitization; Springer International Publishing: Cham, Switzerland, 2018.

32. Valtakoski, A. Explaining servitization failure and deservitization: A knowledge-based perspective. Ind. Mark. Manag. 2017, 60, 138-150. [CrossRef]

33. Kimita, K.; Watanabe, K.; Hara, T.; Komoto, H. Who Realizes a PSS?: An Organizational Framework for PSS Development. Procedia CIRP 2015, 30, 372-377. [CrossRef]

34. Tan, A.; Mcaloone, T.; Matzen, D. Service-Oriented Strategies for Manufacturing Firms. In Introduction to Product/Service-System Design; Sakao, T., Lindahl, M., Eds.; Springer: London, UK, 2009; pp. 197-218.

35. Benedettini, O.; Neely, A.; Swink, M. Why do servitized firms fail? A risk-based explanation. Int. J. Oper. Prod. Manag. 2015, 35, 946-979. [CrossRef]

36. Qu, M.; Yu, S.; Chen, D.; Chu, J.; Tian, B. State-of-the-art of design, evaluation, and operation methodologies in product service systems. Comput. Ind. 2016, 77, 1-14. [CrossRef]

37. Richter, A.; Glaser, P.; Kölmel, B.; Waidelich, L.; Bulander, R. A Review of Product-service System Design Methodologies. In Proceedings of the 16th International Joint Conference on e-Business and Telecommunications, Prague, Czech Republic, 26-28 July 2019; Volume 1, pp. 115-126. [CrossRef]

38. Mendes, G.; Oliveira, M.; Rozenfeld, H.; Marques, C.; Costa, J. Product-Service System (Pss) Design Process Methodologies: A Systematic Literature Review. In Proceedings of the 20th International Conference on Engineering Design (ICED 15), Milan, Italy, 2730 July 2015; pp. 1-10. Available online: https:/ / www.designsociety.org/download-publication/37886/PRODUCT-SERVICE+ SYSTEM+\%28PSS\%29+DESIGN+PROCESS+METHODOLOGIES\%3A+A+SYSTEMATIC+LITERATURE+REVIEW (accessed on 28 February 2021).

39. Haber, N.; Fargnoli, M. Designing product-service systems: A review towards a unified approach. In Proceedings of the International Conference on Industrial Engineering and Operations Management, Rabat, Morocco, 11-13 April 2017; pp. 817-837.

40. Pieroni, M.; Marques, C.; Campes, C.; Guzzo, D.; Mendes, G.; Costa, J.; Rosa, M.; de Oliveira, M.G.; Macul, V.; Rozenfeld, H. Transforming a Traditional Product Offer into PSS: A Practical Application. Procedia CIRP 2016, 47, 412-417. [CrossRef]

41. Barquet, A.P.B.; Steingrímsson, J.G.; Seliger, G.; Rozenfeld, H. Method to create proposals for PSS business models. Procedia CIRP 2015, 30, 13-17. [CrossRef]

42. Adrodegari, F.; Saccani, N.; Perona, M.; Agirregomezkorta, A. Business model innovation: A process model and toolset for servitizing industrial firms. In Practices and Tools for Servitization: Managing Service Transition; Springer: Berlin/Heidelberg, Germany, 2018; pp. 97-120. [CrossRef]

43. Adrodegari, F.; Saccani, N.; Kowalkowski, C. A Framework for PSS Business Models: Formalization and Application. Procedia CIRP 2016, 47, 519-524. [CrossRef]

44. Chiu, M.C.; Chu, C.Y.; Kuo, T.C. Product service system transition method: Building firm's core competence of enterprise. Int. J. Prod. Res. 2019, 57, 1-21. [CrossRef]

45. Helkkula, A.; Kowalkowski, C.; Tronvoll, B. Archetypes of Service Innovation. J. Serv. Res. 2018, 21, 284-301. [CrossRef] [PubMed]

46. Pieroni, M.P.P.; McAloone, T.C.; Pigosso, D.C.A. From theory to practice: Systematising and testing business model archetypes for circular economy. Resour. Conserv. Recycl. 2020, 162, 105029. [CrossRef]

47. Bocken, N.M.P.; Short, S.W.; Rana, P.; Evans, S. A literature and practice review to develop sustainable business model archetypes. J. Clean. Prod. 2014, 65, 42-56. [CrossRef]

48. Waidelich, L.; Bulander, R.; Richter, A.; Kölmel, B.; Glaser, P. A systematic literature review on product-service systems classifications and types. In Proceedings of the 16th International Joint Conference on e-Business and Telecommunications, Prague, Czech Republic, 26-28 July 2019; Volume 1, pp. 89-100. [CrossRef]

49. Blessing, L.T.M.; Chakrabarti, A. DRM, a Design Research Methodology; Springer: London, UK, 2009.

50. Biolchini, J.; Mian, P.G.; Natali, A.C.C.; Travassos, G.H. Systematic Review in Software Engineering; Technical Report ES 679/05; Systems Engineering and Computer Science Department: Rio de Janeiro, Brazil, 2005. Available online: https://www.cos.ufrj.br/ uploadfile/es67905.pdf (accessed on 28 February 2021).

51. Manzini, E.; Vezzoli, C. A strategic design approach to develop sustainable product service systems: Examples taken from the 'environmentally friendly innovation' Italian prize. J. Clean. Prod. 2003, 11, 851-857. [CrossRef]

52. Quinn, M.J. Case-Based Analysis: A Practical Tool for Teaching Computer Ethics. In Proceedings of the 37th SIGCSE Technical Symposium on Computer Science Education, Houston, TX, USA, 1-5 March 2006; pp. 520-524. [CrossRef]

53. Eurostat. NACE Rev. 2-Statistical Classification of Economic Activities. 2008. Available online: https://ec.europa.eu/eurostat/ ramon/nomenclatures/index.cfm?TargetUrl=LST_NOM_DTL\&StrNom=NACE_REV2\&StrLanguageCode=EN\&IntPcKey= \&StrLayoutCode=HIERARCHIC (accessed on 7 November 2020).

54. Weking, J.; Brosig, C.; Böhm, M.; Hein, A.; Krcmar, H. Business Model Innovation Strategies for Product Service Systems-an Explorative Study in the Manufacturing Industry. In Proceedings of the Twenty-Sixth European Conference on Information Systems (ECIS2018), Portsmouth, UK, 23-28 June 2018.

55. Barquet, A.P.B.; de Oliveira, M.G.; Amigo, C.R.; Cunha, V.P.; Rozenfeld, H. Employing the business model concept to support the adoption of product-service systems (PSS). Ind. Mark. Manag. 2013, 42, 693-704. [CrossRef]

56. Wise, R.; Baumgartner, P. Go downstream-The new profit imperative in manufacturing. Harv. Bus. Rev. 1999, 77, $133-141$. 
57. Amarsy, N. How To Scan Your Business Model Environment For Disruptive Threats and Opportunities-Strategyzer. Stretegyzer. 2015. Available online: https://blog.strategyzer.com/posts/2015/10/14/how-to-scan-through-your-environments-disruptivethreats-and-opportunities (accessed on 3 April 2019).

58. Visnjic, I.; Ringov, D.; Arts, S. Which Service? How Industry Conditions Shape Firms' Service-Type Choices. J. Prod. Innov. Manag. 2019, 36, 381-407. [CrossRef]

59. Tan, A.; McAloone, T.C. Characteristics of Strategies in Product/Service-System Development. In Proceedings of the 9th International Design Conference, Dubrovnik, Croatia, 15-18 May 2006; pp. 1435-1442.

60. Yang, M.; Evans, S. Product-service system business model archetypes and sustainability. J. Clean. Prod. 2019, 220 , 1156-1166. [CrossRef]

61. Osterwalder, A.; Pigneur, Y. Business Model Generation; Self Published: Amsterdam, The Netherlands, 2010.

62. Hanski, J.; Kunttu, S.; Räikkönen, M.; Reunanen, M. Development of Knowledge-Intensive Product-Service Systems; VTT Technical Research Centre of Finland: Espoo, Finland, 2012.

63. Pieroni, M.P.P.; McAloone, T.C.; Pigosso, D.C.A. Business model innovation for circular economy and sustainability: A review of approaches. J. Clean. Prod. 2019, 215, 198-216. [CrossRef]

64. Kjaer, L.L.; Pigosso, D.C.A.; McAloone, T.C.; Birkved, M. Guidelines for evaluating the environmental performance of Product/Service-Systems through life cycle assessment. J. Clean. Prod. 2018, 190, 666-678. [CrossRef]

65. Mastrogiacomo, L.; Barravecchia, F.; Franceschini, F. Enabling factors of manufacturing servitization: Empirical analysis and implications for strategic positioning. Proc. Inst. Mech. Eng. Part B J. Eng. Manuf. 2020, 234, 1258-1270. [CrossRef] 